\title{
Chemometrics as a tool to discriminate geographical origin of Cyperus esculentus L. based on chemical composition
}

\author{
Isabel Lopéz-Cortés ${ }^{\mathrm{a}, *}$, Domingo C. Salazar-García ${ }^{\mathrm{b}, \mathrm{c}}$, Ricardo Malheiro ${ }^{\mathrm{d}, \mathrm{e}}$, \\ Vicente Guardiola ${ }^{\mathrm{a}}$, José Alberto Pereira ${ }^{\mathrm{d}}$ \\ a Departamento. Producción Vegetal, Universidad Politécnica de Valencia, Camino de Vera s/n, 46022 Valencia, Spain \\ ${ }^{\mathrm{b}}$ Research Group on Plant Foods in Hominin Dietary Ecology, Max-Planck Institute for Evolutionary Anthropology, Deutscher Platz 6, 04103 Leipzig, \\ Germany \\ ${ }^{\mathrm{c}}$ Department of Human Evolution, Max-Planck Institute for Evolutionary Anthropology, Deutscher Platz 6, 04103 Leipzig, Germany \\ d Mountain Research Centre (CIMO), School of Agriculture, Polytechnic Institute of Bragança, Campus de Santa Apolónia, Apartado 1172, $5301-855$ \\ Bragança, Portugal \\ e REQUIMTE/Laboratory of Bromatology and Hydrology, Faculty of Pharmacy, Porto University, Rua de Jorge Viterbo Ferreira, 228, 4050-313 Porto, Portugal
}

\section{A R T I C L E I N F O}

\section{Article history:}

Received 9 July 2013

Received in revised form 18 August 2013

Accepted 24 August 2013

\section{Keywords:}

Cyperus esculentus $\mathrm{L}$.

Geographical origin

Fatty acids

$\alpha$-Tocopherol

Sterols

Chemometric analysis

\begin{abstract}
A B S T R A C T
In the present study the chemical composition of Cyperus esculentus L. (tiger nut) from four distinct geographical origin (Spain, Egypt, Nigeria, and South Africa) was assessed to observe the possible effect of the cultivation site in the fatty acids profile, sterols composition, and squalene and $\alpha$-tocopherol content.

It was verified that the individual fatty acids as well as the different fatty acids fractions were severely affected by the geographical origin. Tiger nut oils were predominantly monounsaturated with lower prevalence of saturated fatty acids, and with capability to provide appreciable amounts of essential fatty acids. The sterols fraction was affected as well, but in lower extent. $\beta$-sitosterol was the most abundant sterol found, reaching nearly $60 \%$ of the total sterols found in tiger nut oils, with significant differences among geographical origins.

The fatty acids data, together with the sterols and $\alpha$-tocopherol and squalene data were capable to separate tiger nut samples according to their chemical composition and geographical origin when a principal component analysis was applied. The fatty acids profile could be applied as a possible geographical authenticity marker.
\end{abstract}

(c) 2013 Published by Elsevier B.V.

\section{Introduction}

Cyperus esculentus L. is a member of the Cyperaceae family distributed mainly in the Southern European region and in the Western part of Africa. This tuberous perennial crop is popularly known by several designations: tiger nut, earth almond, earth nut, yellow nut sedge, nut grass, water grass, flatsedge, chufa (mainly in Spain), edible rush, edible galingale, rush nut, among others. In Nigeria it is designated by aya, imunu, ofio, aki Hausa, according to the region and ethnic groups where it is inserted (El Bamishaiye and Bamishaiye, 2011). C. esculentus tuberous rhizomes are exploited for human consumption being consumed raw or roasted, for flour production, milk extraction for beverages preparation ("horchata de chufas" in Spain; "kunnu aya" in Northen Nigeria), oil extraction and incorporation of components in food products (Adejuyitan,

\footnotetext{
* Corresponding author. Tel.: +34 963879331.

E-mail address: islocor@upv.es (I. Lopéz-Cortés).
}

2011; El Bamishaiye and Bamishaiye, 2011; Oladele and Aina, 2007; Sánchez-Zapata et al., 2010, 2011, 2012a,b).

The compositional study of tiger nut revealed that they possess low amounts of water, but are rich in fat, fibres, and carbohydrates, being a good source of starch (Arafat et al., 2009; Coşkuner et al., 2002; Ekcanyanwu and Ononogbu, 2010; Oladele and Aina, 2007; Ozcan et al., 2010). Concerning fat composition, tiger nut oils are predominantly monounsaturated, being a good source of essential fatty acids that the human organisms cannot synthesize (Kim et al., 2007; Sánchez-Zapata et al., 2012a; Yeboah et al., 2012). Concerning amino acids composition, tiger nut is rich in glutamic acid, methionine, arginine and aspartic acid. Its mineral composition revealed high amounts of potassium, phosphorous, sodium, calcium, and magnesium (Ekcanyanwu and Ononogbu, 2010; Glew et al., 2006; Oladele and Aina, 2007). According to Chukwuma et al. (2010), several groups of phytochemicals are present in tiger nut, with marked differences between raw and roasted ones. Alkaloids, resins, and sterols are the most abundant compounds followed by cyanogenic glycosides, tannins and saponins (Chukwuma et al., 2010). These compounds could be responsible for the biological 
properties exhibited by tiger nut, like antioxidant activity (Cook et al., 1998), hypolipidemic and anti-obesity effects (El-Anany and Ali, 2012; Moon et al., 2012), antibacterial (Zhao et al., 2005) and anti-obesity properties (Moon et al., 2012).

Meanwhile the studies involving tiger nut samples normally characterize samples from the same geographic origin. For the authors knowledge no studies have been conducted reflecting the chemical composition of tiger nut samples from different geographical origins, in order to study the effect of cultivation site in the chemical composition of chufas. Since many agronomic and edaphoclimatic factors may affect the chemical composition of tiger nut, being the geographical origin a most important factor due to clime and soil particularities, this subject is most worthy to be studied.

In this sense the main objective of this work was to study the chemical composition of tiger nut oil samples from different geographic areas (Spain, Egypt, Nigeria, and South Africa). Samples fatty acids profile, sterols composition, as well as $\alpha$-tocopherol and squalene were performed in order to meet work objectives.

\section{Materials and methods}

\subsection{Chemicals}

Ethanol absolute (99\%) analytical grade, hexane 96\%, methanol $99.8 \%$, petroleum ether of analytical grade, sodium hydroxide 98\%, and sodium chloride $99.5 \%$ were obtained from Scharlau (Barcelona, Spain). Cyclohexane HPLC grade, dodecyl sulphate sodic, 5 - $\alpha$-cholestane- $3 \beta$-ol, pyrogallol ACS reagent and fatty acids and sterols standards were obtained from Sigma-Aldrich (St. Louis, USA). Potassium hydroxide $85 \%$ and hydrochloric acid $4 \%$ in methanol were purchased from Panreac (Barcelona, Spain).

\subsection{C. esculentus L. sampling and oil extraction}

Overall 44 samples of $C$. esculentus distributed by four distinct geographical regions were collected. Twenty two samples were from Spain, more specifically from the province of Valencia; 6 samples were from Egypt; 8 samples were from Nigeria and another 8 samples from South Africa. Each initial sample was composed by $2.5-3 \mathrm{~kg}$ of selected $C$. esculentus tubers in the field and cleaned. From those initial samples 3 subsamples were taken for the extraction of oil in the laboratory. Samples collected in Egypt, Nigeria and South Africa were sealed in individual containers and transported to the laboratory in Spain in adequate conditions and controlled atmosphere.

The fat content of tiger nut tubers was determined using the Soxhlet apparatus at $40-60^{\circ} \mathrm{C}$ with petroleum ether as extracting solvent during $24 \mathrm{~h}$.

\subsection{Fatty acids determination}

Fatty acids profile was determined following the standard UNE 55,037-73. They were analyzed with a CE Instruments GC 8000 Top, with a flame ionization detector (FID), equipped with a Supelcowax 10 column $(30 \mathrm{~mm} \times 0.25 \mathrm{~mm})$. Helium was the carrier gas at a flow of $1 \mathrm{~mL} / \mathrm{min}$. The temperatures of the injector and detector were $250^{\circ} \mathrm{C}$ and $270^{\circ} \mathrm{C}$, respectively, with an injection volume of $1 \mu \mathrm{L}$. The results are expressed in relative percentage of each fatty acid, calculated by internal normalization of the chromatographic peak areas. A fatty acids methyl esters standard mixture (Supelco 37 FAME Mix) was used for identification and calibration purposes.

\subsection{Sterols and tocopherols determination}

The analysis of sterols and tocopherols was made from $100 \mathrm{mg}$ of fat after extraction with cyclohexane, which is subsequently separated with nitrogen and ether of trimethylsilol and injected with a weight of 5,7-dimethyltocol following the technique developed by Slover et al. (1983).

The sterols composition was analyzed in the same equipment used for fatty acids analysis, with a Tracer TR Sterol column $(30 \mathrm{~m} \times 0.22 \mathrm{~mm})$. The temperatures of the injector and the detector were respectively $290^{\circ} \mathrm{C}$ and $300^{\circ} \mathrm{C}$. Oven temperature was set to $265^{\circ} \mathrm{C}$, being injected a volume of $1 \mu \mathrm{L}$.

\subsection{Statistical analysis}

\subsubsection{Analysis of variance}

An analysis of variance (ANOVA) with Type III sums of squares was performed using the GLM (General Linear Model procedure) of the SPSS software, version 19.0 (IBM Corporation, New York, USA). The fulfilment of the ANOVA requirements, namely the normal distribution of the residuals and the homogeneity of variance, were evaluated by means of the Kolmogorov-Smirnov with Lilliefors correction (if $n>50$ ) or the Shapiro-Wilk's test (if $n<50$ ), and the Levene's tests, respectively. All dependent variables were analyzed using a one-way ANOVA with or without Welch correction, depending if the requirement of the homogeneity of variances was fulfilled or not. The main factor studied was the effect of geographical origin of $C$. esculentus samples in the fatty acids profile, $\alpha$-tocopherol content and sterols composition. If a statistical significant effect was found, means were compared using Tukey's honestly significant difference multiple comparison test or Dunnett T3 test also depending if equal variances could be assumed or not. All statistical tests were performed at a $5 \%$ significance level.

\subsubsection{Principal component analysis}

Principal component analysis (PCA) was applied to reduce the number of variables ( 20 variables concerning fatty acids profile and 5 variables concerning sterol composition and $\alpha$-tocopherol content) to a smaller number of new derived variables (principal component or factors) that adequately summarize the original information, i.e., the influence of geographical origin in the chemical composition of $C$. esculentus. One PCA was carried out with 20 variables (fatty acids profile), and a second PCA was performed with the entire data obtained ( 25 variables - fatty acids profile plus sterol composition and $\alpha$-tocopherol content). Moreover, it allowed recognizing patterns in the data by plotting them in a multidimensional space, using the new derived variables as dimensions, principal components or factor scores. The number of factors to keep in data treatment was evaluated by the Scree plot, taking in consideration the eigenvalues and the internal consistency by means of $\alpha$-Cronbach's value (Rencher, 1995). PCA was performed by using SPSS software, version 19.0 (IBM Corporation, New York USA).

\section{Results and discussion}

\subsection{Fatty acids profile of C. esculentus samples}

Samples of tiger nut (C. esculentus) from different origins were assessed for their fatty acids profile. In Table 1 are reported the main fatty acids found in the samples from Spain, while in Table 2 is presented the fatty acids profile of tiger nuts from Egypt, Nigeria and South Africa. The most abundant fatty acids were the same in all samples independently from their origin. Oleic acid $\left(C_{18: 1}\right)$ was the most abundant fatty acid, reporting marked differences among samples from different regions (between $51.81 \%$ and $75.43 \%$ ). 
Table 1

Fatty acids composition ( $\mathrm{g} / 100 \mathrm{~g}$ of fatty acids) of tiger nut samples from Spain.

\begin{tabular}{|c|c|c|c|c|c|c|c|c|c|c|c|c|c|c|c|c|}
\hline Sample & $C_{12: 0}$ & $C_{14: 0}$ & $C_{15: 0}$ & $C_{16: 0}$ & $C_{16: 1}$ & $C_{17: 0}$ & $C_{18: 0}$ & $C_{18: 1}$ & $C_{18.2}$ & $\mathrm{C}_{18.3}$ & $C_{20: 0}$ & $C_{22: 0}$ & $C_{24: 0}$ & SFA & MUFA & PUFA \\
\hline S-1 & 0.04 & 0.09 & 0.02 & 14.48 & 0.25 & 0.07 & 2.50 & 73.66 & 8.26 & 0.16 & 0.37 & 0.06 & 0.04 & 17.67 & 73.91 & 8.42 \\
\hline S-2 & 0.04 & 0.09 & 0.02 & 15.09 & 0.25 & 0.06 & 2.81 & 73.23 & 7.75 & 0.17 & 0.34 & 0.05 & 0.09 & 18.60 & 73.48 & 7.92 \\
\hline S-3 & 0.04 & 0.07 & 0.02 & 13.45 & 0.25 & 0.07 & 2.85 & 75.43 & 7.30 & 0.14 & 0.34 & 0.05 & 0.00 & 16.89 & 75.67 & 7.44 \\
\hline S-4 & 0.03 & 0.08 & 0.02 & 13.86 & 0.25 & 0.07 & 2.79 & 74.74 & 7.62 & 0.15 & 0.33 & 0.05 & 0.00 & 17.24 & 74.98 & 7.77 \\
\hline S-5 & 0.03 & 0.08 & 0.02 & 13.48 & 0.26 & 0.08 & 2.39 & 73.70 & 9.26 & 0.28 & 0.36 & 0.06 & 0.00 & 16.50 & 73.96 & 9.54 \\
\hline S-6 & 0.06 & 0.09 & 0.01 & 13.33 & 0.25 & 0.06 & 3.08 & 74.59 & 7.94 & 0.16 & 0.35 & 0.06 & 0.00 & 17.06 & 74.84 & 8.10 \\
\hline$S-7$ & 0.02 & 0.07 & 0.02 & 14.07 & 0.25 & 0.07 & 2.64 & 73.41 & 8.86 & 0.21 & 0.34 & 0.06 & 0.00 & 17.27 & 73.66 & 9.07 \\
\hline S-8 & 0.08 & 0.13 & 0.02 & 15.72 & 0.23 & 0.09 & 3.75 & 72.87 & 6.19 & 0.15 & 0.40 & 0.05 & 0.08 & 20.43 & 73.23 & 6.34 \\
\hline S-9 & 0.05 & 0.10 & 0.02 & 15.83 & 0.24 & 0.07 & 2.50 & 72.34 & 8.32 & 0.17 & 0.27 & 0.03 & 0.06 & 18.95 & 72.58 & 8.49 \\
\hline S-10 & 0.05 & 0.11 & 0.02 & 16.00 & 0.30 & 0.06 & 3.00 & 71.29 & 8.59 & 0.21 & 0.29 & 0.03 & 0.04 & 19.60 & 71.59 & 8.81 \\
\hline S-11 & 0.06 & 0.11 & 0.02 & 16.99 & 0.32 & 0.06 & 2.54 & 70.89 & 8.49 & 0.18 & 0.24 & 0.03 & 0.04 & 20.13 & 71.21 & 8.67 \\
\hline S-12 & 0.06 & 0.11 & 0.02 & 16.17 & 0.30 & 0.06 & 3.23 & 71.14 & 8.33 & 0.22 & 0.29 & 0.04 & 0.05 & 20.02 & 71.44 & 8.54 \\
\hline S-13 & 0.05 & 0.09 & 0.01 & 15.93 & 0.21 & 0.06 & 2.46 & 72.90 & 7.76 & 0.14 & 0.26 & 0.03 & 0.06 & 18.99 & 73.11 & 7.90 \\
\hline S-14 & 0.05 & 0.08 & 0.02 & 16.45 & 0.25 & 0.07 & 2.01 & 72.75 & 7.80 & 0.12 & 0.24 & 0.03 & 0.04 & 19.04 & 73.04 & 7.92 \\
\hline S-15 & 0.07 & 0.11 & 0.02 & 17.65 & 0.30 & 0.07 & 2.18 & 71.21 & 7.82 & 0.14 & 0.24 & 0.03 & 0.08 & 20.51 & 71.57 & 7.96 \\
\hline S-16 & 0.06 & 0.10 & 0.02 & 15.71 & 0.27 & 0.06 & 2.45 & 73.02 & 7.82 & 0.18 & 0.26 & 0.03 & 0.00 & 18.71 & 73.29 & 8.00 \\
\hline S-17 & 0.06 & 0.10 & 0.02 & 17.29 & 0.33 & 0.08 & 2.18 & 69.12 & 10.18 & 0.28 & 0.26 & 0.04 & 0.05 & 20.09 & 69.45 & 10.46 \\
\hline S-18 & 0.06 & 0.10 & 0.02 & 17.07 & 0.26 & 0.06 & 2.15 & 70.76 & 9.06 & 0.19 & 0.24 & 0.03 & 0.00 & 19.74 & 71.02 & 9.25 \\
\hline S-19 & 0.06 & 0.09 & 0.02 & 17.88 & 0.27 & 0.07 & 2.09 & 69.62 & 9.34 & 0.20 & 0.25 & 0.03 & 0.00 & 20.52 & 69.93 & 9.54 \\
\hline S-20 & 0.06 & 0.10 & 0.02 & 16.22 & 0.23 & 0.06 & 2.19 & 72.06 & 8.63 & 0.14 & 0.24 & 0.04 & 0.00 & 18.93 & 72.30 & 8.77 \\
\hline S-21 & 0.05 & 0.14 & 0.01 & 18.03 & 0.28 & 0.05 & 2.41 & 69.79 & 8.67 & 0.19 & 0.14 & 0.17 & 0.00 & 21.01 & 70.13 & 8.86 \\
\hline S-22 & 0.07 & 0.11 & 0.04 & 15.97 & 0.35 & 0.05 & 2.34 & 73.97 & 6.76 & 0.14 & 0.13 & 0.04 & 0.00 & 18.89 & 74.32 & 6.90 \\
\hline Mean & 0.05 & 0.10 & 0.02 & 15.76 & 0.27 & 0.07 & 2.57 & 72.39 & 8.22 & 0.18 & 0.28 & 0.05 & 0.03 & 19.01 & 72.61 & 8.39 \\
\hline SD & 0.01 & 0.02 & 0.01 & 1.43 & 0.03 & 0.01 & 0.41 & 1.68 & 0.86 & 0.04 & 0.07 & 0.03 & 0.03 & 1.34 & 1.72 & 0.94 \\
\hline
\end{tabular}

$\mathrm{SFA}=\Sigma\left(\mathrm{C}_{6: 0}+\mathrm{C}_{8: 0}+\mathrm{C}_{10: 0}+\mathrm{C}_{12: 0}+\mathrm{C}_{14: 0}+\mathrm{C}_{15: 0}+\mathrm{C}_{16: 0}+\mathrm{C}_{17: 0}+\mathrm{C}_{18: 0}+\mathrm{C}_{20: 0}+\mathrm{C}_{22: 0}+\mathrm{C}_{24: 0}\right) ; \mathrm{MUFA}=\Sigma\left(\mathrm{C}_{16: 1}+\mathrm{C}_{18: 1}+\mathrm{C}_{22: 1}\right) ; \mathrm{PUFA}=\Sigma\left(\mathrm{C}_{18: 2}+\mathrm{C}_{18: 3}\right)$.

Spanish samples reported higher mean values (72.39\% - ranging between $69.12 \%$ and $75.43 \%$ ), followed by Egyptian samples (71.69\% - from $71.23 \%$ to $72.03 \%$ ), South African samples (62.95\% - from $62.17 \%$ to $63.82 \%$ ); and finally by Nigerian samples which reported a mean value of $59.44 \%$ (from $51.81 \%$ to $61.23 \%$ ). Palmitic acid $\left(C_{16: 0}\right)$, the second most abundant fatty acid reported higher values in the samples from South Africa (20.38\%), followed by Nigeria (17.87\%), and Spain (15.76\%). On the other hand samples from Egypt reported lower $\mathrm{C}_{16: 0}$ values, $15.15 \%$.

Linoleic acid $\left(C_{18: 2}\right)$ was the third main fatty acid found in all tiger nut samples (Tables 1 and 2). Its mean values ranged from $8.22 \%$ to $10.91 \%$, respectively in samples from Spain and South Africa. The three fatty acids discussed earlier $\left(C_{18: 1} ; C_{16: 0}\right.$; and $\left.C_{18: 2}\right)$ reported significant differences among regions $(P<0.001$ for

Table 2

Fatty acids composition (g/100 g of fatty acids) of tiger nut samples from Africa (Egypt, Nigeria, and South Africa).

\begin{tabular}{|c|c|c|c|c|c|c|c|c|c|c|c|c|c|c|c|c|}
\hline Sample & $C_{12: 0}$ & $C_{14: 0}$ & $C_{15: 0}$ & $C_{16: 0}$ & $C_{16: 1}$ & $C_{17: 0}$ & $C_{18: 0}$ & $C_{18: 1}$ & $C_{18.2}$ & $C_{18.3}$ & $C_{20: 0}$ & $C_{22: 0}$ & $C_{24: 0}$ & SFA & MUFA & PUFA \\
\hline \multicolumn{17}{|l|}{ Egypt } \\
\hline E-1 & 0.05 & 0.12 & 0.02 & 14.74 & 0.26 & 0.06 & 3.81 & 71.63 & 8.69 & 0.00 & 0.42 & 0.08 & 0.12 & 19.43 & 71.89 & 8.69 \\
\hline E-2 & 0.06 & 0.10 & 0.02 & 14.61 & 0.27 & 0.07 & 3.69 & 71.73 & 8.45 & 0.08 & 0.44 & 0.07 & 0.11 & 19.18 & 72.03 & 8.53 \\
\hline E-3 & 0.05 & 0.09 & 0.02 & 15.23 & 0.26 & 0.07 & 3.21 & 71.82 & 8.63 & 0.06 & 0.39 & 0.05 & 0.10 & 19.21 & 72.10 & 8.69 \\
\hline E-4 & 0.06 & 0.04 & 0.02 & 15.13 & 0.25 & 0.06 & 2.99 & 72.03 & 8.43 & 0.05 & 0.24 & 0.06 & 0.12 & 18.72 & 72.36 & 8.48 \\
\hline E-5 & 0.05 & 0.03 & 0.02 & 16.11 & 0.26 & 0.06 & 3.18 & 71.69 & 7.99 & 0.01 & 0.36 & 0.07 & 0.09 & 19.98 & 71.97 & 8.00 \\
\hline E-6 & 0.05 & 0.07 & 0.01 & 15.09 & 0.27 & 0.06 & 3.23 & 71.23 & 8.64 & 0.06 & 0.40 & 0.07 & 0.08 & 19.06 & 71.54 & 8.70 \\
\hline Mean & 0.05 & 0.07 & 0.02 & 15.15 & 0.26 & 0.06 & 3.35 & 71.69 & 8.47 & 0.04 & 0.37 & 0.07 & 0.10 & 19.26 & 71.98 & 8.52 \\
\hline SD & 0.01 & 0.03 & 0.00 & 0.53 & 0.01 & 0.01 & 0.32 & 0.26 & 0.26 & 0.03 & 0.07 & 0.01 & 0.02 & 0.42 & 0.27 & 0.27 \\
\hline \multicolumn{17}{|l|}{ Nigeria } \\
\hline $\mathrm{N}-1$ & 0.04 & 0.17 & 0.01 & 17.89 & 0.27 & 0.07 & 3.96 & 59.78 & 9.64 & 0.10 & 0.41 & 0.06 & 0.10 & 22.73 & 60.05 & 9.74 \\
\hline $\mathrm{N}-2$ & 0.02 & 0.18 & 0.00 & 18.13 & 0.26 & 0.07 & 3.81 & 61.23 & 8.64 & 0.13 & 0.40 & 0.05 & 0.09 & 22.76 & 61.50 & 8.77 \\
\hline $\mathrm{N}-3$ & 0.03 & 0.16 & 0.01 & 17.73 & 0.27 & 0.08 & 3.91 & 61.18 & 8.59 & 0.12 & 0.39 & 0.04 & 0.01 & 22.36 & 61.48 & 8.71 \\
\hline $\mathrm{N}-4$ & 0.04 & 0.16 & 0.01 & 16.94 & 0.26 & 0.06 & 3.84 & 61.23 & 9.61 & 0.13 & 0.38 & 0.07 & 0.07 & 21.58 & 61.49 & 9.74 \\
\hline N-5 & 0.04 & 0.17 & 0.01 & 17.23 & 0.26 & 0.06 & 3.64 & 60.23 & 8.24 & 0.11 & 0.37 & 0.08 & 0.08 & 21.69 & 60.50 & 8.35 \\
\hline N-6 & 0.05 & 0.15 & 0.00 & 18.03 & 0.27 & 0.07 & 3.58 & 60.13 & 8.18 & 0.11 & 0.40 & 0.06 & 0.09 & 22.43 & 60.42 & 8.29 \\
\hline N-7 & 0.04 & 0.14 & 0.00 & 18.41 & 0.26 & 0.06 & 3.81 & 51.81 & 8.61 & 0.12 & 0.41 & 0.06 & 0.01 & 22.94 & 52.07 & 8.73 \\
\hline N-8 & 0.04 & 0.18 & 0.01 & 18.63 & 0.26 & 0.07 & 3.79 & 59.93 & 8.64 & 0.11 & 0.40 & 0.00 & 0.04 & 23.16 & 60.19 & 8.75 \\
\hline Mean & 0.04 & 0.16 & 0.01 & 17.87 & 0.26 & 0.07 & 3.79 & 59.44 & 8.77 & 0.12 & 0.39 & 0.05 & 0.06 & 22.46 & 59.71 & 8.88 \\
\hline SD & 0.01 & 0.01 & 0.01 & 0.57 & 0.00 & 0.01 & 0.13 & 3.14 & 0.56 & 0.01 & 0.01 & 0.02 & 0.04 & 0.57 & 3.15 & 0.56 \\
\hline \multicolumn{17}{|c|}{ South Africa } \\
\hline SA-1 & 0.08 & 0.21 & 0.02 & 21.36 & 0.35 & 0.08 & 3.66 & 62.86 & 10.89 & 0.11 & 0.28 & 0.03 & 0.04 & 25.79 & 63.21 & 11.00 \\
\hline SA-2 & 0.08 & 0.18 & 0.01 & 18.75 & 0.31 & 0.06 & 5.34 & 63.81 & 10.90 & 0.11 & 0.35 & 0.04 & 0.06 & 24.88 & 64.12 & 11.01 \\
\hline SA-3 & 0.09 & 0.22 & 0.02 & 21.23 & 0.31 & 0.08 & 3.84 & 62.59 & 11.12 & 0.11 & 0.29 & 0.03 & 0.04 & 25.87 & 62.90 & 11.24 \\
\hline SA-4 & 0.08 & 0.19 & 0.01 & 21.34 & 0.32 & 0.08 & 3.63 & 62.93 & 10.83 & 0.11 & 0.27 & 0.03 & 0.03 & 25.70 & 63.25 & 10.94 \\
\hline SA-5 & 0.09 & 0.22 & 0.02 & 19.63 & 0.33 & 0.09 & 4.19 & 62.59 & 10.69 & 0.10 & 0.33 & 0.02 & 0.02 & 24.64 & 62.92 & 10.79 \\
\hline SA-6 & 0.08 & 0.21 & 0.01 & 18.98 & 0.34 & 0.07 & 3.94 & 63.82 & 10.90 & 0.10 & 0.31 & 0.02 & 0.02 & 23.67 & 64.16 & 11.00 \\
\hline SA-7 & 0.08 & 0.22 & 0.02 & 20.63 & 0.33 & 0.08 & 4.18 & 62.85 & 11.03 & 0.12 & 0.32 & 0.01 & 0.01 & 25.57 & 63.18 & 11.15 \\
\hline SA-8 & 0.08 & 0.19 & 0.01 & 21.12 & 0.35 & 0.08 & 3.63 & 62.17 & 10.89 & 0.11 & 0.33 & 0.02 & 0.02 & 25.50 & 62.52 & 11.00 \\
\hline Mean & 0.08 & 0.20 & 0.01 & 20.38 & 0.33 & 0.08 & 4.05 & 62.95 & 10.91 & 0.11 & 0.31 & 0.02 & 0.03 & 25.20 & 63.28 & 11.02 \\
\hline SD & 0.00 & 0.02 & 0.00 & 1.09 & 0.01 & 0.01 & 0.57 & 0.58 & 0.13 & 0.01 & 0.03 & 0.01 & 0.02 & 0.76 & 0.58 & 0.13 \\
\hline
\end{tabular}


the three fatty acids). Besides that these fatty acids are classified, respectively, as monounsaturated fatty acids (MUFA), saturated fatty acids (SFA), and polyunsaturated fatty acids (PUFA), being each one the main fatty acid according to their class. Consequently, SFA, MUFA and PUFA contents were affected as well according to the samples geographical origin, with recorded marked significant differences $(P<0.001$ for each fat fraction). In this sense, MUFA is the main fraction of tiger nut oils, compressing between $59.71 \%$ and $72.61 \%$ of all fatty acids (respectively in Nigerian and Spanish tiger nut samples). SFA content vary between $19.01 \%$ and $25.20 \%$, while PUFA values oscillated between $8.39 \%$ and $11.02 \%$, possible values reporting respectively to Spanish and South African samples (Tables 1 and 2). The contents reported in the Spanish and Egyptian tiger nut samples are quite in accordance to the profile obtained by Sánchez-Zapata et al. (2012a), while the profile observed in the Nigerian and South African samples was different. Concerning Nigerian samples, the low values of $C_{18: 1}$ recorded are higher than those reported by Eteshola and Oraedu (1996) and lower than those reported by Laseka and Abdulkarim (2012), which worked with tiger nuts from the same country. The fatty acids profile exhibited by the samples of Egypt is in accordance to that reported by Arafat et al. (2009). However El-Anany and Ali (2012) reported higher percentage of $C_{18: 2}$ and consequently higher PUFA, by studying tiger nut oils from Egypt. The differences found in the samples from different regions could result from several agronomic factors, such as, the maturation of tiger nuts, the variety studied; but also from edaphoclimatic reasons, such as, the climate conditions, soil composition and properties, and human agricultural practices. All these factors influence the chemical composition of tiger nut samples.

The fatty acids composition of tiger nut fat is considerably similar to that presented by olive oil (Malheiro et al., 2012, 2013), a world recognized vegetable oil for its flavour and healthy properties. Nutritionally tiger nut oil is a rich source of essential fatty acids, and present respectively ratios of MUFA/SFA and $C_{18: 1} / C_{16: 0}$ above 3 and 4 for Spanish and Egyptian samples, while Nigerian and South African samples reported ratios below 3 and 4 .

Observed the results obtained in the fatty acids profile of tiger nut samples from four different geographical origins, a principal component analysis (PCA) was performed. For the author's knowledge, the application of chemometrics to geographical differentiation purposes of tiger nut has never been conducted. Only one work was carried out with authentication purposes of the P.D.O. (Protected Designation of Origin) of "horchata de Valencia", a beverage where tiger nut is the main ingredient, regarding their mineral content (Boeting et al., 2010; Temple et al., 1990, 1991).

By using two principal factors, or principal components, $56.45 \%$ of the variance could be explained, $38.03 \%$ in the first factor and $18.42 \%$ in the second factor. In Fig. 1 it is inferred that the fatty acids profile allowed the creation of four distinct groups, each group according to the samples provenience. Samples from South Africa were those who reported a more differentiated profile. These samples, represented in the positive and negative regions of the first and second factors respectively, were characterized due to being richer in saturated fatty acids (SFA) and polyunsaturated fatty acids (PUFA). Concerning SFA, myristic acid $\left(C_{14: 0}\right)$, palmitic acid $\left(C_{16: 0}\right)$, and margaric acid $\left(C_{17: 0}\right)$ were found in higher content in South African samples. Palmitoleic acid $\left(C_{16: 1}\right)$, and linoleic acid $\left(C_{18: 2}\right)$, the major PUFA, also characterized these samples.

The samples from Nigeria were represented in the positive regions of both factors due to higher content in arachidic acid $\left(C_{20: 0}\right)$. Samples from Egypt and Spain were represented in the negative region of the first factor. Spanish samples were more abundant in monounsaturated fatty acids (MUFA) due to the high content in oleic acid $\left(\mathrm{C}_{18: 1}\right)$, but were also abundant in linolenic acid $\left(C_{18: 3}\right)$, and pentadecanoic acid $\left(C_{15: 0}\right)$. Egyptian samples were

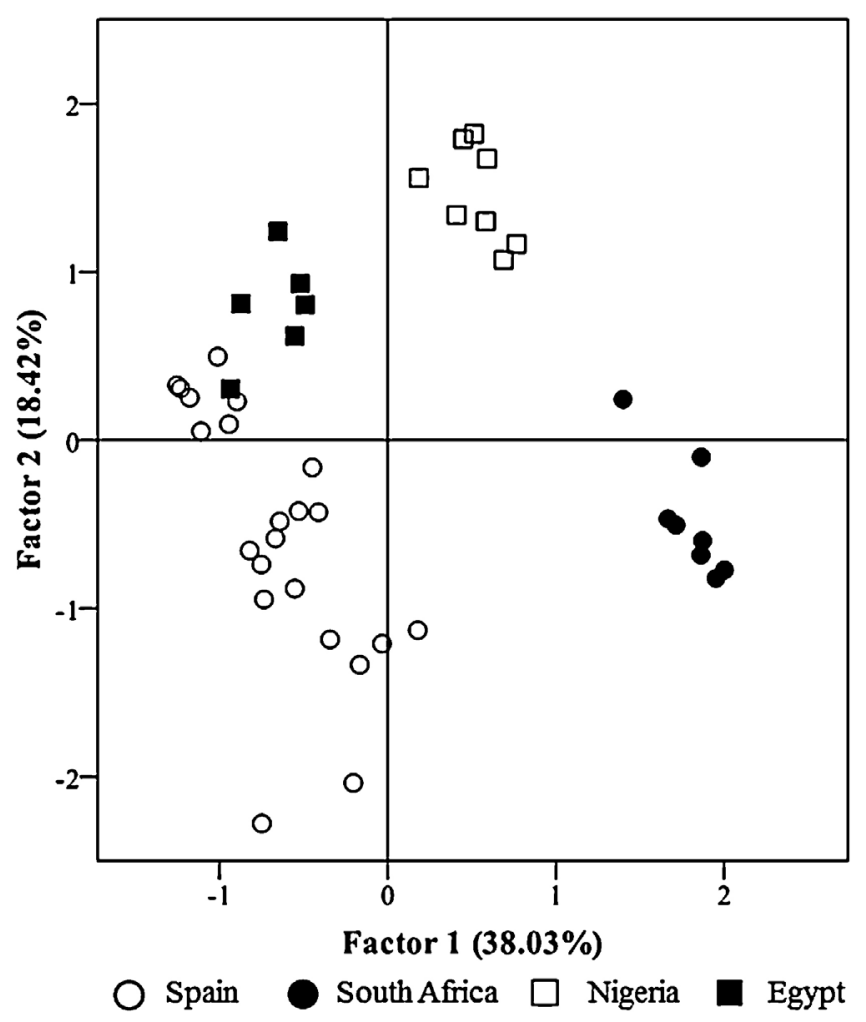

Fig. 1. Principal components analysis obtained from the fatty acids profile of tiger nut samples from Spain, Egypt, Nigeria and South Africa. PCA factors explain 56.45\% of the total variance.

richer in SFA, although being minority in the $C$. esculentus oil, namely, behenic acid $\left(C_{22: 0}\right)$ and lignoceric acid $\left(C_{24: 0}\right)$.

The results obtained in PCA are a valuable asset in order to authenticate tiger nut provenience, and therefore be a useful tool in terms of traceability and authentication purposes for the P.D.O. "horchata de Valencia".

\section{2. $\alpha$-Tocopherol, squalene and sterols composition}

The tiger nut oils from the samples of different regions were studied to quantify minor compounds, namely $\alpha$-tocopherol and sterols. The results obtained in the Spanish samples are reported in Table 3, while those from the Egyptian, Nigerian and South African samples are reported in Table 4. $\alpha$-Tocopherol reported higher content in the samples from Egypt, with a median value of $28.7 \mu \mathrm{g} / \mathrm{g}$, being this tocopherol found in all samples. However in the remaining samples it was only found at vestigial amounts. In Spanish samples it was only identified in 4 of the 22 samples, ranging from $0 \mu \mathrm{g} / \mathrm{g}$ to $65.2 \mu \mathrm{g} / \mathrm{g}$, reporting a median value of $4.6 \mu \mathrm{g} / \mathrm{g}$. In Nigerian samples was reported in 3 of the 8 samples with $0.1 \mu \mathrm{g} / \mathrm{g}$, while in South African samples it was identified in only one sample with the same $0.1 \mu \mathrm{g} / \mathrm{g}$.

Concerning squalene content, samples from Egypt reported significantly higher values $(103.3 \mu \mathrm{g} / \mathrm{g} ; P<0.001)$ comparatively with the remaining samples. Samples from Spain, South Africa and Nigeria reported respectively $53.2 \mu \mathrm{g} / \mathrm{g}, 52.0 \mu \mathrm{g} / \mathrm{g}$ and $40.6 \mu \mathrm{g} / \mathrm{g}$ (Tables 3 and 4).

Total sterols content increase in the following order: Egypt $\quad(728.7 \mu \mathrm{g} / \mathrm{g})<$ Spain $\quad(939 \mu \mathrm{g} / \mathrm{g})<$ South $\quad$ Africa $(948.2 \mu \mathrm{g} / \mathrm{g})<$ Nigeria $(962.1 \mu \mathrm{g} / \mathrm{g})$. $\beta$-Sitosterol was the most abundant sterol, varying between $59.6 \%$ (Egypt samples) and 64.5\% (South Africa samples) of total sterols. Its absolute values achieved $611.5 \mu \mathrm{g} / \mathrm{g}$ in the samples from South Africa, being $\beta$-sitosterol present with significantly low content in the samples 
Table 3

Squalene, $\alpha$-tocopherol, and sterols composition of tiger nut samples from Spain (results expressed as $\mu \mathrm{g} / \mathrm{g}$ ).

\begin{tabular}{|c|c|c|c|c|c|}
\hline Samples & Squalene & $\alpha$-Tocopherol & Campesterol & Stigmasterol & $\beta$-Sitosterol \\
\hline S-1 & 33.4 & 19.4 & 142.8 & 194.5 & 585.7 \\
\hline $\mathrm{S}-2$ & 33.9 & 0.0 & 155.6 & 189.8 & 609.4 \\
\hline$S-3$ & 45.2 & 0.0 & 134.0 & 197.0 & 615.7 \\
\hline$S-4$ & 50.3 & 0.0 & 129.7 & 200.1 & 615.1 \\
\hline S-5 & 66.5 & 0.0 & 141.5 & 204.1 & 585.0 \\
\hline S-6 & 61.4 & 65.2 & 128.8 & 197.2 & 547.4 \\
\hline S-7 & 83.5 & 0.0 & 113.8 & 191.2 & 605.0 \\
\hline$S-8$ & 25.7 & 0.0 & 127.8 & 230.9 & 601.4 \\
\hline S-9 & 42.7 & 0.0 & 149.0 & 201.2 & 594.9 \\
\hline$S-10$ & 49.1 & 0.0 & 135.0 & 173.1 & 638.5 \\
\hline S-11 & 51.1 & 0.0 & 126.8 & 164.0 & 645.9 \\
\hline S-12 & 40.8 & 0.0 & 115.3 & 188.2 & 648.9 \\
\hline S-13 & 78.9 & 0.0 & 149.8 & 193.4 & 577.9 \\
\hline S-14 & 91.1 & 0.0 & 148.2 & 189.3 & 568.7 \\
\hline S-15 & 64.7 & 0.0 & 149.3 & 196.2 & 589.8 \\
\hline S-16 & 34.4 & 0.0 & 147.7 & 222.7 & 595.3 \\
\hline S-17 & 49.4 & 0.0 & 155.7 & 220.7 & 574.2 \\
\hline S-18 & 63.6 & 0.0 & 148.9 & 201.9 & 585.6 \\
\hline S-19 & 37.8 & 0.0 & 154.2 & 193.2 & 614.8 \\
\hline S-20 & 41.0 & 10.7 & 152.3 & 202.9 & 586.4 \\
\hline S-21 & 67.6 & 0.0 & 135.0 & 165.8 & 631.6 \\
\hline S-22 & 59.0 & 5.8 & 141.3 & 172.9 & 622.7 \\
\hline Mean & 53.2 & 4.6 & 140.1 & 195.0 & 601.8 \\
\hline SD & 17.4 & 14.3 & 12.5 & 16.7 & 25.9 \\
\hline Minimum & 25.7 & 0.0 & 113.8 & 164.0 & 547.4 \\
\hline Maximum & 91.1 & 65.2 & 155.7 & 230.9 & 648.9 \\
\hline
\end{tabular}

Table 4

Squalene, $\alpha$-tocopherol, and sterols composition of tiger nut samples from Egypt, Nigeria, and South Africa (results expressed as $\mu$ g/g).

\begin{tabular}{|c|c|c|c|c|c|}
\hline Samples & Squalene & $\alpha$-Tocopherol & Campesterol & Stigmasterol & $\beta$-Sitosterol \\
\hline \multicolumn{6}{|l|}{ Egypt } \\
\hline E-1 & 103.4 & 28.9 & 114.4 & 179.3 & 430.1 \\
\hline E-2 & 103.2 & 28.8 & 114.1 & 178.9 & 442.3 \\
\hline E-3 & 103.1 & 28.5 & 114.3 & 178.4 & 436.5 \\
\hline E-4 & 103.6 & 28.4 & 114.2 & 179.1 & 431.7 \\
\hline E-5 & 103.4 & 28.9 & 114.4 & 176.5 & 435.4 \\
\hline E-6 & 103.3 & 28.8 & 114.7 & 178.8 & 430.1 \\
\hline Mean & 103.3 & 28.7 & 114.4 & 178.5 & 434.4 \\
\hline SD & 0.2 & 0.2 & 0.2 & 1.0 & 4.7 \\
\hline Minimum & 10.31 & 28.4 & 114.1 & 176.5 & 430.1 \\
\hline Maximum & 10.36 & 28.9 & 114.7 & 179.3 & 442.3 \\
\hline \multicolumn{6}{|l|}{ Nigeria } \\
\hline $\mathrm{N}-1$ & 40.7 & 0.0 & 166.3 & 187.1 & 606.0 \\
\hline $\mathrm{N}-2$ & 40.3 & 0.1 & 166.2 & 187.0 & 601.0 \\
\hline $\mathrm{N}-3$ & 40.6 & 0.1 & 166.5 & 186.6 & 612.1 \\
\hline $\mathrm{N}-4$ & 40.7 & 0.0 & 166.3 & 189.9 & 601.4 \\
\hline $\mathrm{N}-5$ & 40.8 & 0.0 & 166.2 & 190.1 & 612.5 \\
\hline $\mathrm{N}-6$ & 40.7 & 0.0 & 166.1 & 188.0 & 612.2 \\
\hline $\mathrm{N}-7$ & 40.4 & 0.0 & 166.3 & 190.6 & 604.5 \\
\hline $\mathrm{N}-8$ & 40.5 & 0.1 & 166.2 & 181.2 & 615.9 \\
\hline Mean & 40.6 & 0.0 & 166.3 & 187.6 & 608.2 \\
\hline SD & 0.2 & 0.1 & 0.1 & 3.0 & 5.7 \\
\hline Minimum & 40.3 & 0.0 & 166.1 & 181.2 & 601.0 \\
\hline Maximum & 40.8 & 0.1 & 166.5 & 190.6 & 615.9 \\
\hline \multicolumn{6}{|l|}{ South Africa } \\
\hline SA-1 & 63.0 & 0.0 & 144.6 & 166.6 & 620.4 \\
\hline SA-2 & 37.5 & 0.0 & 176.3 & 171.7 & 609.0 \\
\hline SA-3 & 35.6 & 0.0 & 160.2 & 193.2 & 595.1 \\
\hline SA-4 & 62.1 & 0.0 & 160.2 & 175.4 & 616.5 \\
\hline SA-5 & 36.5 & 0.0 & 160.5 & 177.6 & 616.7 \\
\hline SA-6 & 60.2 & 0.1 & 175.4 & 164.7 & 599.9 \\
\hline SA-7 & 61.2 & 0.0 & 156.4 & 165.2 & 612.4 \\
\hline SA-8 & 59.8 & 0.0 & 172.4 & 173.2 & 622.3 \\
\hline Mean & 52.0 & 0.0 & 163.2 & 173.5 & 611.5 \\
\hline SD & 12.9 & 0.0 & 10.8 & 9.3 & 9.7 \\
\hline Minimum & 35.6 & 0.0 & 144.6 & 164.7 & 595.1 \\
\hline Maximum & 63.0 & 0.1 & 176.3 & 193.2 & 622.3 \\
\hline
\end{tabular}




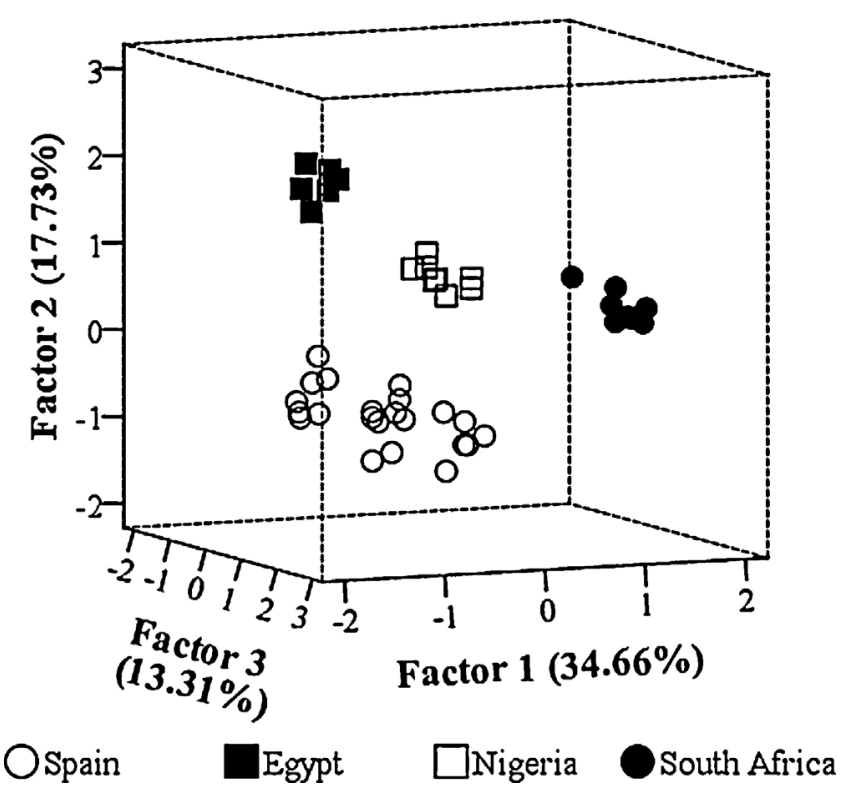

Fig. 2. Principal components analysis obtained from the combination of fatty acids profile and contents of squalene, $\alpha$-tocopherol, stigmasterol, campesterol, and $\beta$ sitosterol of tiger nut samples from Spain, Egypt, Nigeria and South Africa. PCA factors explain $65.70 \%$ of the total variance.

from Egypt (434.4 $\mu \mathrm{g} / \mathrm{g} ; \mathrm{P}<0.001)$. Stigmasterol and campesterol reported mean values between $100 \mu \mathrm{g} / \mathrm{g}$ and $200 \mu \mathrm{g} / \mathrm{g}$ in all samples. Campesterol mean values varied between $114.4 \mu \mathrm{g} / \mathrm{g}$ and $166.3 \mu \mathrm{g} / \mathrm{g}$, respectively in the samples from Egypt and Nigeria. In fact, campesterol reported significantly lower values in the samples from Egypt and significantly higher values in those samples from Nigeria and South Africa $(P<0.001)$. In the case of stigmasterol a lower variance was observed among samples from different origins. South African samples reported lower mean values $(173.5 \mu \mathrm{g} / \mathrm{g})$ and samples from Spain higher ones $(195.0 \mu \mathrm{g} / \mathrm{g})$. Comparatively with the sterols composition of tiger nut oil from Ghana, the results obtained in our samples are quite similar to those obtained by Yeboah et al. (2012).

In this case, since tiger nut oils are poor in SFA, richer in unsaturated fatty acids, and contain considerable amounts of sterols, they may be consider a good fat source, and may low the risk in the occurrence of cardiovascular diseases.

Combining the results obtained in the fatty acids profile together with squalene, $\alpha$-tocopherol, and sterols composition, another PCA was developed to try to see the influence of geographical origin in the tiger nut oil composition. In this new PCA three principal factors were used, explaining $65.7 \%$ of the total variance (Fig. 2). As observed in Fig. 2 the separation of the samples according to their origin was achieved. The tendency observed in the PCA displayed in Fig. 1 concerning the fatty acids profile is maintained. In this new PCA, samples from South Africa (in the positive regions of the three factors) and Nigeria were characterized due to high campesterol content. Spanish tiger nuts were more abundant in stigmasterol, while Egyptian tiger nuts were highly rich in squalene and $\alpha$-tocopherol. The inclusion of such new variables in study aids in the differentiation of the samples. Furthermore, such results corroborate that the fatty acids profile can be used as geographical markers of tiger nut samples, being possible to differentiate the samples according to their origin.

\section{Conclusions}

The study of tiger nut samples from different regions brought to light that the cultivation site has a tremendous effect in the composition of the final oil obtained. Fatty acids profile and sterols composition, as well as $\alpha$-tocopherol and squalene contents were affected according to the tiger nut's origin. The samples analyzed revealed that tiger nuts oil is rich in monounsaturated fatty acids with a lower prevalence of saturated fat. Furthermore, they are composed by sterols with biological importance, which increases the nutritional value of the oil. Applying chemometric tools to the data obtained it was possible to differentiate the samples according to their origin. The fatty acids profile could be used as geographical authenticity markers to attest the provenience of tiger nut samples.

\section{References}

Adejuyitan, J.A., 2011. Tigernut processing: its food uses and health benefits. American Journal of Food Technology 6, 197-201.

Arafat, S.M., Gaafar, A.M., Basuny, A.M., Nassef, S.L., 2009. Chufa tubers (Cyperus esculentus L.): as a new source of food. World Applied Sciences Journal 7, 151-156.

Boeting, K., Benzo, Z.A., Cervera, M.L., Guardia, M., 2010. Authentication of the protected designation of origin horchata de Valencia through the chemometric treatment of mineral content. Analytical Methods 2, 1723-1728.

Chukwuma, E.R., Obioma, N., Christopher, O.I., 2010. The phytochemical composition and some biochemical effects of Nigerian tigernut (Cyperus esculentus L.) tuber. Pakistan Journal of Nutrition 9, 709-715.

Cook, J.A., VanderJagt, D.J., Dasgupta, A., Mounkaila, G., Glew, R.S., Blackwell, W. Glew, R.H., 1998. Use of Trolox assay to estimate the antioxidant activity content of seventeen edible wild plants of Niger. Life Sciences 63, 106-110.

Coşkuner, Y., Ercan, R., Karababa, E., Nazlican, A.N., 2002. Physical and chemical properties of chufa (Cyperus esculentus L) tubers grown in the Çukurova region of Turkey. Journal of the Science of Food and Agriculture 82, 625-631.

El-Anany, A.M., Ali, R.F.M., 2012. Studies on the hypolipidemic effects of Coconut oil when blended with tiger nut oil and fed to albino rats. Grasas y Aceites 63, 303-312.

Ekcanyanwu, R.C., Ononogbu, C.I., 2010. Nutritive value of Nigerian tigernut (Cyperus esculentus L.). Agricultural Journal 5, 297-302.

El Bamishaiye, Bamishaiye, O.M., 2011. Tiger nut: as a plant, its derivatives and benefits. African Journal of Food, Agriculture, Nutrition and Development 11, 5157-5170.

Eteshola, E., Oraedu, A.C.I., 1996. Fatty acid compositions of tigernut tubers (Cyperus esculentus L.), baobab seeds (Adansonia digitata L.), and their mixture. Journal of the American Oil Chemists' Society 73, 255-257.

Glew, R.H., Glew, R.S., Chuang, L.-T., Huang, Y.-S., Millson, M., Constans, D., Vanderjagt, D.J., 2006. Amino acid, mineral and fatty acid content of pumpkin seeds (Cucurbita spp.) and Cyperus esculentus nuts in the Republic of Niger. Plant Foods for Human Nutrition 61, 51-56.

Kim, M., No, S., Yoon, S.H., 2007. Stereospecific analysis of fatty acid composition of Chufa (Cyperus esculentus L.) tuber oil. Journal of the American Oil Chemists' Society 84, 1079-1080.

Laseka, O., Abdulkarim, S.M., 2012. Extraction of oil from tiger nut (Cyperus esculentus L. ) with supercritical carbon dioxide $\left(\mathrm{SC}-\mathrm{CO}_{2}\right)$. LWT Food Science and Technology 47, 287-292.

Malheiro, R., Casal, S., Lamas, H., Bento, A., Pereira, J.A., 2012. Can tea extracts protect extra virgin olive oil from oxidation during microwave heating? Food Research International 48, 148-154.

Malheiro, R., Casal, S., Teixeira, H., Bento, A., Pereira, J.A., 2013. Effect of olive leaves addition during the extraction process of over mature fruits on olive oil quality. Food and Bioprocess Technology 6, 509-521.

Moon, M.K., Ahn, J., Lee, H., Ha, T.Y., 2012. Anti-obesity and hypolipidemic effects of chufa (Cyperus esculentus L.) in mice fed a high-fat diet. Food Science and Biotechnology 21, 317-322.

Oladele, A.K., Aina, J.O., 2007. Chemical composition and functional properties of flour produced from two varieties of tigernut (Cyperus esculentus). African Journal of Biotechnology 6, 2473-2476.

Ozcan, M.M., Gumuscu, A., Er, F., Arslan, D., Ozkalp, B., 2010. Chemical and fatty acid composition of Cyperus esculentus. Chemistry of Natural Compounds 46, 276-277.

Rencher, A.C., 1995. Methods of Multivariate Analysis. Wiley, New York.

Sánchez-Zapata, E., Díaz-Vela, J., Pérez-Chavela, M.L., Pérez-Alvarez, J.A., FernándezLópez, J., 2011. Evaluation of the effect of tiger nut fibre as a carrier of unsaturated fatty acids rich oil on the quality of dry-cured sausages. Food and Bioprocess Technology, http://dx.doi.org/10.1007/s11947-011-0733-1.

Sánchez-Zapata, E., Fernández-López, J., Pérez-Alvarez, J.A., 2012a. Tiger nut (Cyperus esculentus) commercialization: health aspects, composition, properties, and food applications. Comprehensive Reviews in Food Science and Food Safety 11 366-377.

Sánchez-Zapata, E., Pérez-Alvarez, J.A., Fernández-López, J., 2012b. Effects of tiger nut (Cyperus esculentus) milk liquid co-products on the quality of pork burgers. International Journal of Food Science \& Technology http://dx.doi.org/10.1111/j.1365-2621.2012.03089.x.

Sánchez-Zapata, E., Muñoz, C.M., Fuentes, E., Fernández-López, J., Sendra, E., Sayas E., Navarro, C., Pérez-Alvarez, J.A., 2010. Effect of tiger nut fiber on quality characteristics of pork burger. Meat Science 85, 70-76. 
Slover, H.T., Thompson, R.H., Merola, G.V., 1983. Tocopherol and sterol determination by capillary gas chromatography. Journal of the American Oil Chemists' Society 60, 1524-1528.

Temple, V.J., Onobun, C.E., Ojobe, T.O., 1991. Chemical composition of livingstone potato tubers (Plectranthus esculentus). Journal of the Science of Food and Agriculture 56, 127-215.

Temple, V., Ojobe, T.O., Kapu, M.M., 1990. Chemical-analysis of tiger nut (Cyperus esculentus). Journal of the Science of Food and Agriculture 50, 261-263.
Yeboah, A.O., Mitei, Y.C., Ngila, J.C., Wessjohann, L., Schmidt, J., 2012. Compositional and structural studies of the oils from two edible seeds: tiger nut, Cyperus esculentum, and asiato, Pachira insignis, from Ghana. Food Research International 47, 259-266.

Zhao, L.C., Liu, X., Chen, Y.Q., 2005. Preliminary study of chufa functional components in preserving water chestnut cake. Food Science 26 422-424. 